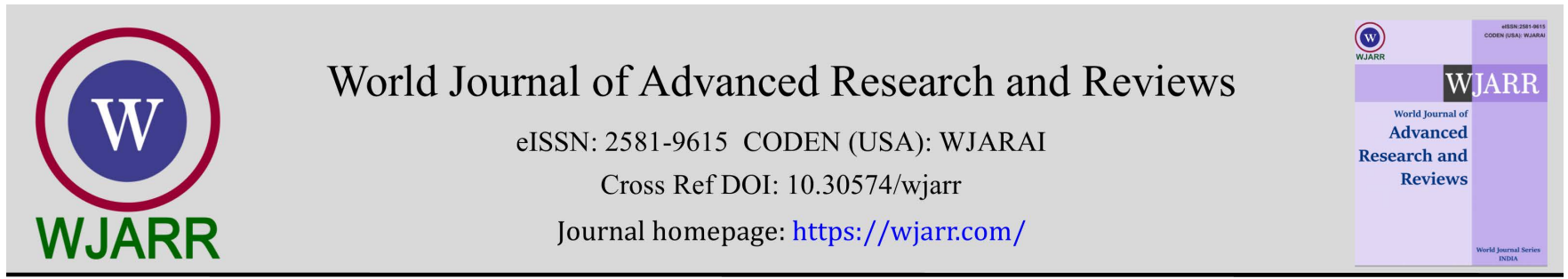

(RESEARCH ARTiClE)

Check for updates

\title{
Dynamics land use in the Lake Chad area of Niger: Between climatic pejoration and anthropization
}

\author{
Laouali Abdoulkadri 1, ${ }^{*}$, Abdou Maman Manssour 2, Bachir Amadou ${ }^{3}$ and Alzouma Zoubérou Mayaki 4 \\ ${ }^{1}$ Department of socio-economics agricultural, Faculty of Agronomic Sciences, Boubacar Bâ University of Tillabéry, BP: \\ 175, Tillabéry, Niger. \\ ${ }^{2}$ Department of Environmental Sciences, Faculty of Agronomic Sciences, Boubacar Bâ University of Tillabéry, BP: 175, \\ Tillabéry, Niger. \\ ${ }^{3}$ Department suvi-evaluation and capitalization, High Commission for Initiative 3N, Niamey, Niger. \\ 4 Department of Biology, Faculty of Science and Technology, Abdou Moumouni University of Niamey, Niger.
}

World Journal of Advanced Research and Reviews, 2021, 09(02), 068-075

Publication history: Received on 15 January 2021; revised on 8 February 2021; accepted on 10 February 2021

Article DOI: https://doi.org/10.30574/wjarr.2021.9.2.0039

\begin{abstract}
This article analyses the dynamics land use in the Lake Chad area located in the Extreme East of the Nigerien territory in the region of Diffa. The study was conducted by using the approach "Land-Use and Land-Cover Change (LULCC." The digital satellite pictures Landsat TM for the year 1990, Landsat ETM for the year 2010 and Landsat ETM for the year 2018 were used. The analysis of the soil occupation indicated some significant changes of the milieu. The food and market gardening crops produced during the period of low tide are abandoned because of insecurity in the lake's bed. The first unit of soil occupation in 1990 with $31 \%$ of coverage rate, covers, in 2018, only $1.26 \%$ of the surface taken into consideration. At the same time, the vegetations (dense enough and thick) with Prosopis juliflora in the Lake's bed expand and densify more because of the improvement in rainfalls in the area in recent years. The dynamics is also observed with the installation of pluvial crops on more than $19 \%$ of the surface taken into consideration at the expenses of the degraded shrub steppes which has lost more than $28 \%$ of its surface in relation to that of 1990 . The return of the lake waters in the area on a surface of more than 13,000 hectares was added to it. The study also enabled to understand the relation to space of the various rural actors in a context where the access to natural resources is a major stake and the object of competition between users.
\end{abstract}

Keywords: Land use; Climatic variability; Lake Chad; Diffa

\section{Introduction}

Since the 1970s, the Sahel has faced a strong degradation of its productive potentials. This degradation was due to the effects of a climatic situation which is globally hostile doubled with a high rate of demographic growth [1]. Niger, a Sahelian country, totally landlocked and three quarters of its surface desert, undergoes this phenomenon in a harsh way. The climate of Niger is characterized by a big interannual variability in rainfall which is affected by dry years which have become more and more frequent from 1968 [2]. The environment remains hostile and the ecosystems are confronted with enormous difficulties related notably to climate variability, but also to a quick increase in population with a growth rate of $3.4 \%$ a year. It is one of the West African countries more affected by climate crises (drought, flooding, etc). In fact, the population of Niger estimated at about 20 million, is mainly rural (83\%). Almost 45\% of this population lives in poverty; $5.5 \%$ live in severe poverty and $13.4 \%$ in extreme poverty [3]. This population draws most of its livelihood means from natural resources, notably from agriculture, cattle breeding and picking.

\footnotetext{
* Corresponding author: Laouali Abdoulkadri

Faculty of Agronomic Sciences, Boubacar Bâ University of Tillabéry, BP : 175, Tillabéry, Niger..
}

Copyright (c) 2021 Author(s) retain the copyright of this article. This article is published under the terms of the Creative Commons Attribution Liscense 4.0. 
As the other regions of Niger, Diffa has faced a climatic pejoration since the 1970 s. located at the extreme part of the territory of Niger, the region of Diffa is between $10^{\circ} 30^{\prime}$ and $15^{\circ} 35^{\prime}$ of Longitude Est, $13^{\circ} 04^{\prime}$ and $18^{\circ} 00^{\prime}$ of Latitude North with a surface of 156, $906 \mathrm{Km} 2$. The relief is made of plains and sandhill plateau characterized by lacustrine and alluvium formations in its Southern part and aeolian formations in the North. Thus, the major part of the population is concentrated in the southern stripe of the region (Figure 1).

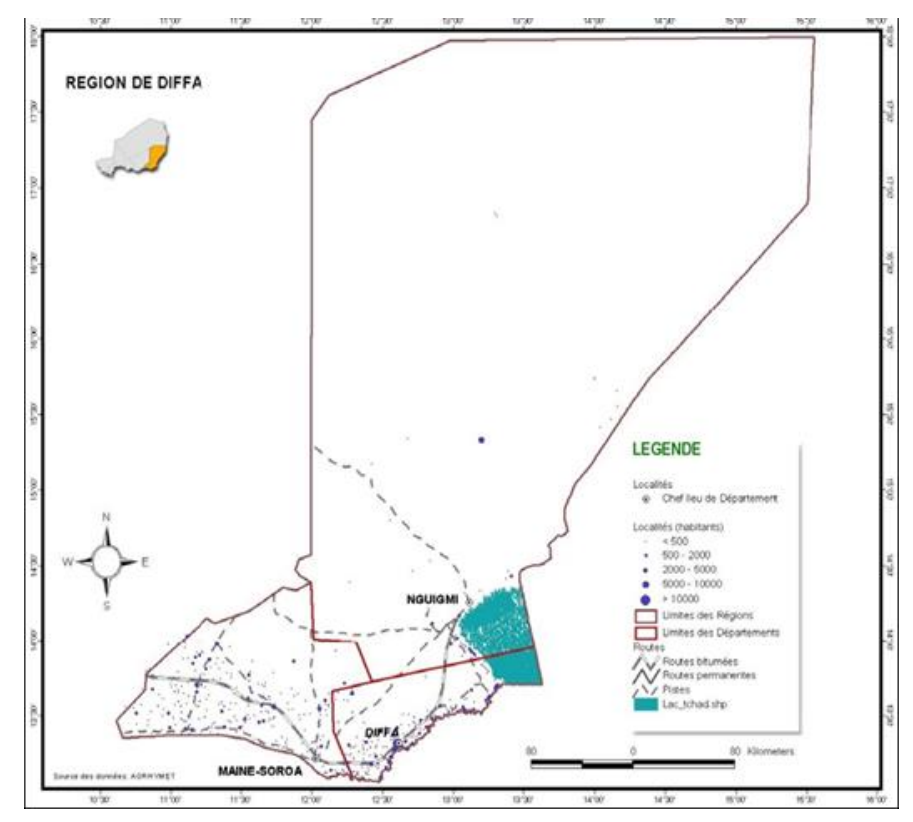

Figure 1 Spatial occupation of the population in the Diffa region. Source: [4]

The climate of the region is of saharo-sahalian type. It is subdivided into three areas according to the agro-ecological potentials. They are: the area of pastoral basins, in the North, between the isohyet 150 to $250 \mathrm{~mm}$ a year. It corresponds to the saharo-sahalian stripe. Cattle breeding is the main economic activity of the population in this area. In the South, there is the area of Komadougou located along the Komadougou Yobé river which is $150 \mathrm{~km}$ long. It receives 250 to 300 $\mathrm{mm}$ of rainfall a year. Agriculture (irrigated and /or during the period of low tide) constitutes the main economic activity of the population. In the East, there is the Lake Chad Basin. It receives 250 to $300 \mathrm{~mm}$ of rainfall a year and agriculture (mostly during the period of low tide) represents the main economic activity of the population in the area. It is also the zone of retreat par excellence for cattle farmers. This makes Diffa one of the pastoral regions par excellence in Niger. However, since the 1970s, the climate is characterized by the succession of more and more constant dry periods. This climatic variability results in repetitive shocks on the population as well as the natural resources. They participate in the formation of the biotic and abiotic environment of the area.

This article tries to analyze the dynamics of land occupation at the level of the region over a period of 28 years through the case of the Lake Chad Basin area. The occupation of lands refers to the various natural, physical and anthropic activities of the soils in consideration. Already in 1972, the Conference of Stockholm on human environment called on a deep study of changes in the use of lands throughout the world. This was reaffirmed in 1992 at the United Nations Conference on environment and development (Prakasam, 2010). Thus, the study was conducted by using the approach "Land-Use and Land-Cover Change (LULCC." [5; 6; 7; 8] on the basis of the satellite pictures of 1990, 2010 et 2018.

\section{Material and methods}

\subsection{Material}

The material used in the framework of this work is of two folds, the database and the software for the processing of images and the production of maps.

For the Database, there are: 
- Digital satellite pictures Landsat TM (Thematic Mapper) for the year 1990, recorded between February and March and Landsat ETM (Enhanced Thematic Mapper) for the year 2018, recorded between December and January.

- Topographic maps at $1 / 200,000$; bibliographic data.

- For the software, there are:

- Erdas Imagine software for the processing of pictures (colored composition, spectral increase, cutting out of interest zones).

- ArcGis software for map production (interpretation on screen, finalization of the geographic database, dressing and generation of attributable tables for the analysis).

- Microsoft EXCEL 2010 software for the processing of tabular data.

\subsection{Method}

From the available satellite pictures (1990, 2010 and 2018), some captures of images of the Lake Chad Basin area were made, then analyzed following an ensemble of well-defined processes. The following steps are developed below:

\subsubsection{Pe-processing of digital pictures}

Its aim is to improve the visual quality of the satellite pictures and analyze well the occupation of soils through these pictures. First, we did a colored composition through superposition of strips. The colored composition in false colors with the close infrared strip (4), the red strip (3), and the blue strip (2) of the Landsat sensor was chosen to facilitate the reading of these strips. Then, for the purpose of having a good visualization of the pictures, an improvement of contrast was carried out by spectral increase of the scenes of images. Thus, the improvement of contrast by equalization of histogram was chosen among the range of possibilities that offers the software ERDAS IMAGINE for the processing of pictures

\subsubsection{Interpretation of the pictures}

The pictures were directly interpreted on the screen on the basis of a clarification made from the information coming from technical documents obtained during the documentary research as well as the visits of reconnaissance on the field. Some keys of interpretation by category of soil occupation were determined.

In total, nine thematic categories were selected in the area as soil occupation units. These are the shrub steppe, degraded shrub steppe, food and market gardening crops produced during the period of low tide, pluvial crops, dense enough vegetation of the lake bed, thick vegetation of the lake bed, pond, river, and lake.

All these units were delimited by digitization thanks to the ArcGIS digitization module and thus constitute the geographic database of the occupation of soils on which all other cartographic analyses and processing will focus. With the help of these database, three-unit tables of soil occupation (1990, 2010 and 2018) were established. The lines and the columns bear proportion values of surfaces occupied (ha and /or \%) by each unit of soil occupation at the corresponding date. These values are obtained by making the sum of the surfaces of all the delimited polygons for the soil occupation unit under consideration and so on up to the last occupation unit.

The crossing of the attribute tables enabled to establish a square matrix describing in a condensed way, the changes of state of the thematic categories on the period taken into account (28 years).

The processing and the analysis of the data from the satellite pictures and their comparison with the data observed on the field in the area enabled, on the one hand, to elaborate the different maps of soil occupation for the area, and, on the other hand, make a diagnostic assessment of the territorial dynamics between 1990 and 2018. The different thematic categories selected definitely during the classification constitute the legend of the occupation maps elaborated.

\section{Results}

\subsection{Spatial analysis of the changes in the area}

First, it consists in interpreting the satellite pictures of the years 1990, 2010 and 2018 and in the definition of the different categories of soil occupations. Second, the comparison of these results with the data from the direct 
observations on the field enabled to refine the analysis and definitely fix the categories of soil occupation and appreciate their dynamics by the comparison between the three situations (1990, 2010 and that of 2018).

The analysis of Figures 2, 3 and 4 shows an important modification of the area's landscape, notably with the return of the Lake's waters (Figure 4) over more than 13,000 hectares (that is 3\% of the surface under consideration). In fact, between 1990 and 2010, the food crops (maize) and market gardening crops produced during the period of low tide, the dense enough vegetation of the lake's bed as well as the degraded shrub steppe represent the most prevailing units of soil occupation. The most prevailing unit is that of food and market gardening crops produced during the period of low tide whose surface is in constant increase with an annual growth rate of $1.7 \%$ per year. This increase in surface happened at the expense of the dense enough vegetation of the lake's bed which diminished by about $1.7 \%$ per year over the same period. The surface of food crops has also increased following the clearing that underwent the shrub steppe in the Southern part, notably in the triangle Fedaga-Kiari Kaari-N'gongouro. However, this last one is in increase towards the North on the axis Malam Djogori-Toumour-N'Gouwa and Gamgara with an annual growth rate of $1.2 \%$. Also, the dynamics of soil occupation is characterized by a considerable extension of thick vegetation whose coverage rate went from $1.2 \%$ in 1990 to $2.5 \%$ in 2010 . In 2018, this rate of coverage reached $10.57 \%$ at the expense of the adjoining dense enough vegetation and of the food and market gardening crops produced during the period of low tide whose coverage went from 184,205.52 hectares in 2010 (41\% of the surface under consideration) to 5,583,81 hectares $(1.26 \%$ of the rate of coverage). At the same time, the dense enough vegetation of the lake's bed expanded its coverage to the zone of food crops and, beyond, to the degraded shrub steppe towards the west integrating the lands of the villages of Kindjandi and of Malam Djogori with an onset of formation of shrub steppe. Thus, the rate of coverage of the dense enough vegetation went from $30.97 \%$ in 1990 to $39.62 \%$ in 2018 (an annual increase rate of - 0,12\%). It mainly concentrates alongside the Komadougou river.

The dynamics is also observed with the appearance of two new units in 2018 which are the pluvial crops and the return of the lake's waters. The installation of pluvial crops expands on the axis Inglea-Barwa Gana- Tchoukoudjani-Boula BrinMamouri as well as in the degraded shrub steppe in the West and covers a surface of more than 85,000 hectares, that is $19.24 \%$ of the surface under consideration.

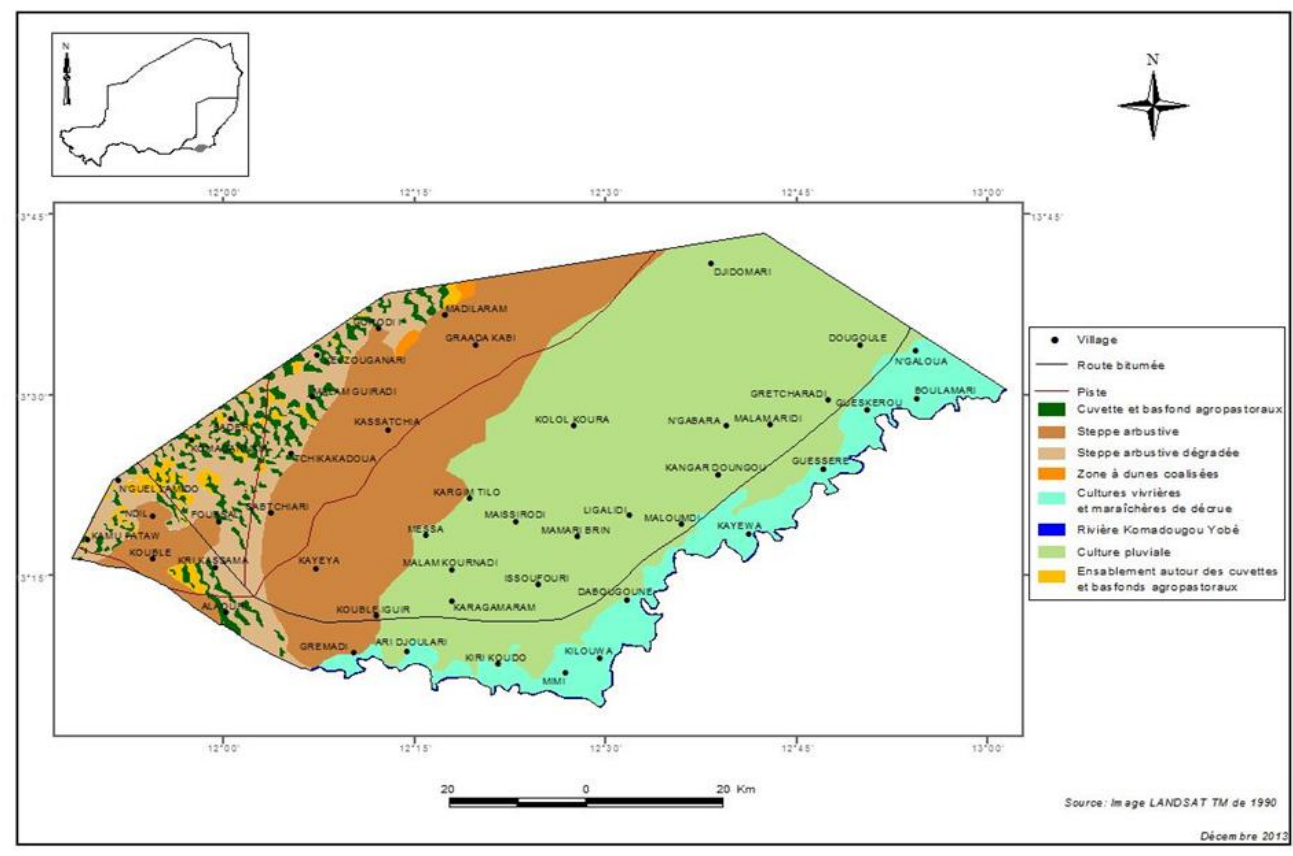

Figure 2 Land use map in the Lake Chad area in 1990. 


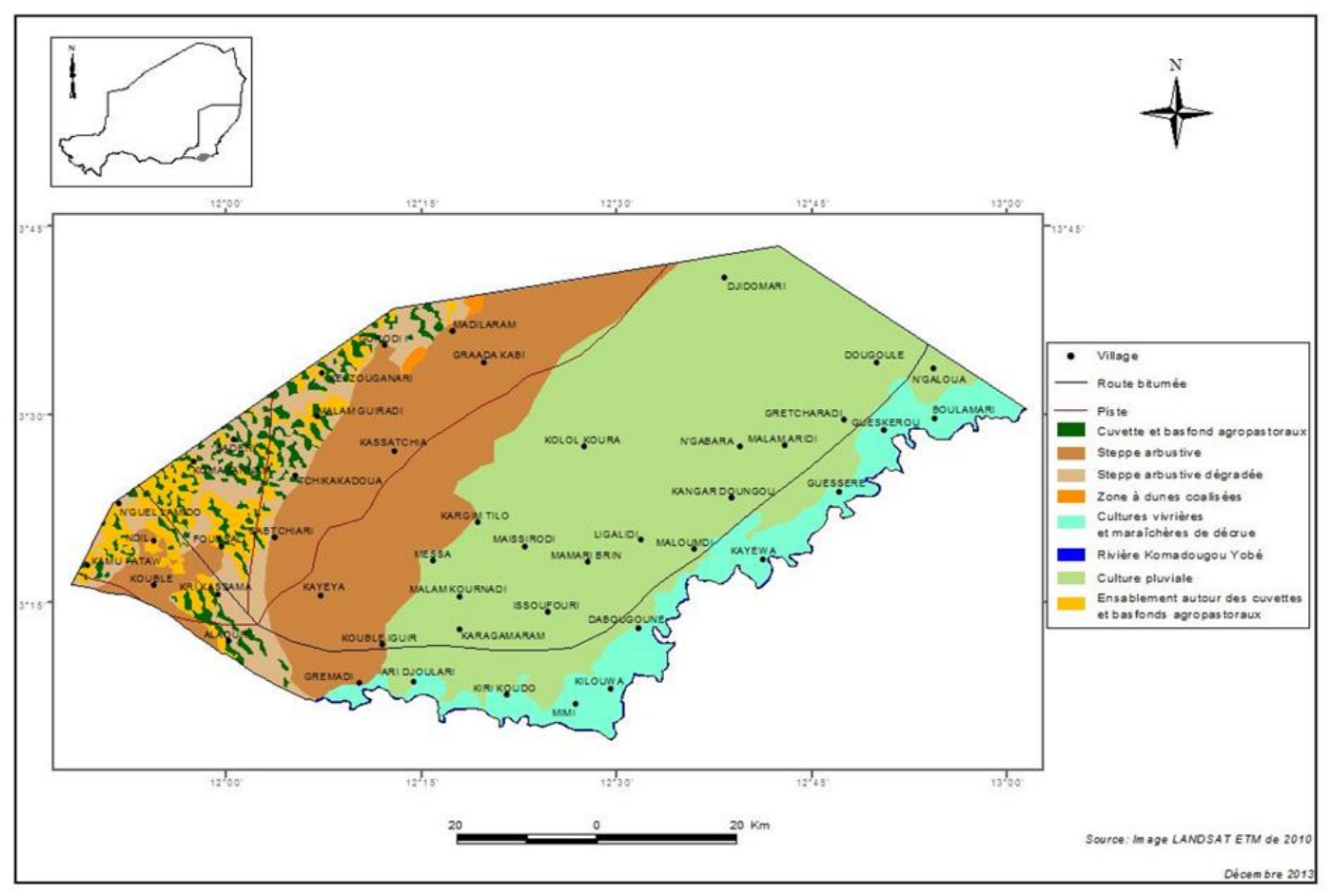

Figure 3 Land use map in the Lake Chad area in 2010.

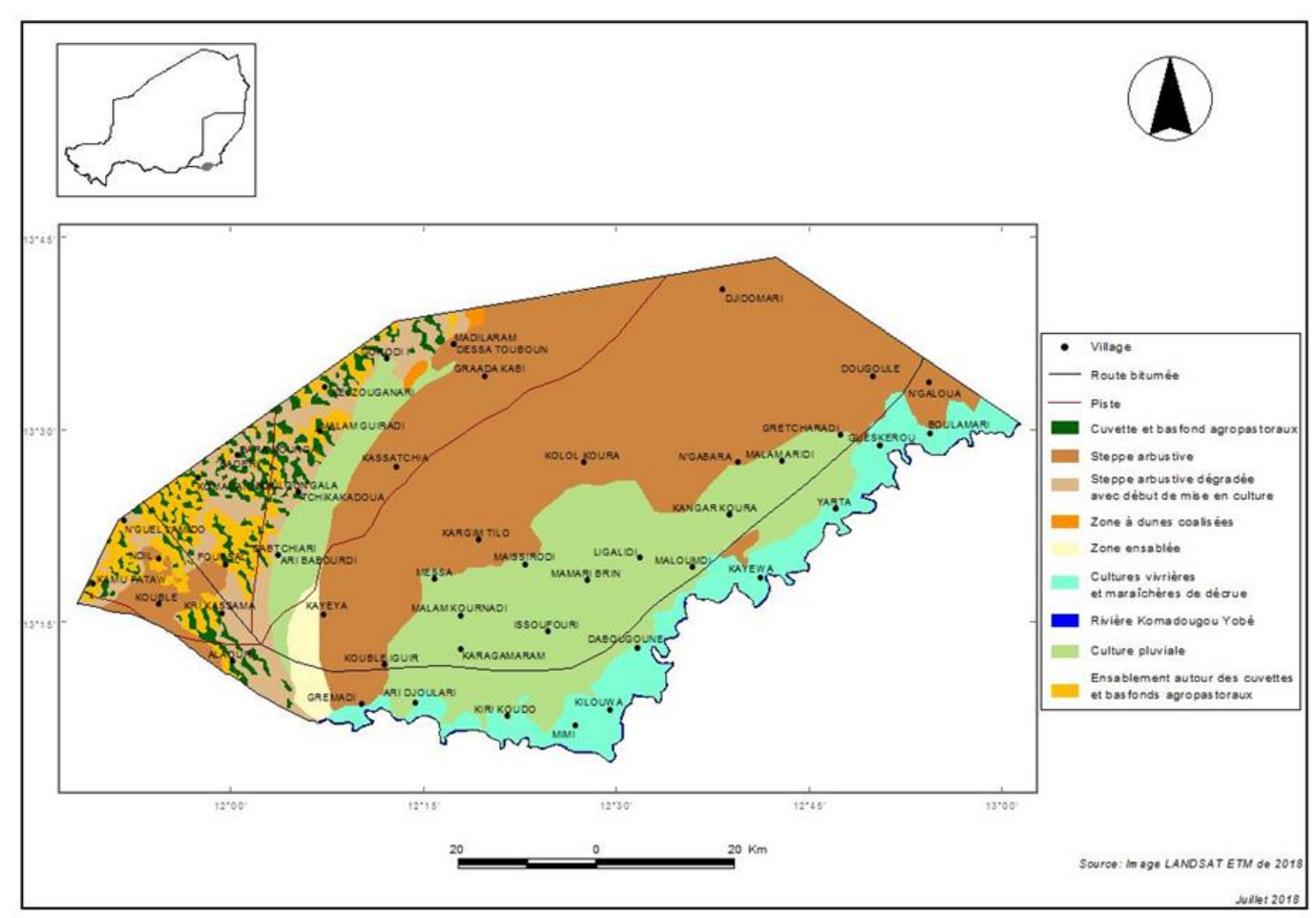

Figure 3 Land use map in the Lake Chad area in 2018.

In other respects, the shrub steppe in the village lands of Fedaga, N'gongouro, N'gouwa, Toumour and Bague face an advanced degradation with an onset of farming on the axis Fedaga-Bague. 


\subsection{Diagnostic assessment of soil occupation dynamics and natural resources}

It comes out from the table 1 that the degraded shrub steppe made of Leptadenia pyrotechnica and Calotropis procera, and the dense enough vegetation of the lake's bed, constitute the main natural plant formations that one observes in the Lake Chad Basin. However, the degraded shrub steppe is in continuous decrease over the period passing from $28.6 \%$ in 1990 to $20.5 \%$ in 2018.

Table 1 Dynamics of the units of soil occupation in the Lake Chad Basin $(1990,2010,2018)$.

\begin{tabular}{|l|l|l|l|l|}
\hline \multicolumn{1}{|c|}{ Kears } & $\mathbf{1 9 9 0}$ & $\mathbf{2 0 1 0}$ & $\mathbf{2 0 1 8}$ & Appreciation \\
\cline { 2 - 5 } & $\begin{array}{l}\text { Coverage } \\
\text { rate (\%) }\end{array}$ & $\begin{array}{l}\text { Coverage } \\
\text { rate (\%) }\end{array}$ & $\begin{array}{l}\text { Coverage } \\
\text { rate (\%) }\end{array}$ & \\
\hline Shrub steppe & 7,3 & 9,08 & 5,59 & Decrease \\
\hline Degraded shrub steppe & 28,6 & 26,23 & 20,50 & Decrease \\
\hline $\begin{array}{l}\text { Food and vegetable crops } \\
\text { during withdrawal of the lake }\end{array}$ & 31 & 41,61 & 1,26 & Decrease \\
\hline $\begin{array}{l}\text { Rather dense vegetation of the } \\
\text { lake bed }\end{array}$ & 31 & 20,38 & 39,62 & Increase \\
\hline $\begin{array}{l}\text { Very dense vegetation of the } \\
\text { lake bed }\end{array}$ & 1,2 & 2,50 & 10,57 & Increase \\
\hline Komadougou Yobé River & 0,2 & 0,19 & 0,19 & Stagnation \\
\hline Mare & 0,03 & 0,03 & 0,03 & Stagnation \\
\hline Pluvial crops & - & - & 19,24 & $\begin{array}{l}\text { New occupancy } \\
\text { unit }\end{array}$ \\
\hline Lake's waters & - & - & 3 & $\begin{array}{l}\text { Return of the } \\
\text { waters }\end{array}$ \\
\hline TOTAL & 100 & 100 & 100 & \\
\hline
\end{tabular}

In the contrary, even if the dense enough vegetation of the Lake's bed is in constant evolution with a surface increase of about $28 \%$ over the period taken into account, this evolution is presented in two phases. A phase of surface decrease between 1990 and 2010 which passes from 31\% of rate of coverage in 1990 to 20.38\% in 2018. The second phase is marked by an increase in surface which goes from 90,209.80 hectares in 2010 to 175,424.31 hectares in 2018, that is a surface increase of more than $94 \%$ in eight years. The thick vegetation progresses in an exponential way. It passes from $1.2 \%$ of coverage in 1990 to more than $10 \%$ in 2018 . The return of the lake's waters in the area is added to it on a surface of more than 13,000 hectares.

Over the period taken into account, the steppe (shrub and degraded shrub), lost about 43,576 hectares, that is $27.39 \%$ of its surface in 1990. At the same time, the surface puts into farming (pluvial, during the period of low tide and /or irrigated) has decreased by about $90,763.33$ hectares, which is $66.15 \%$ of its surface in 1990 , in favor of the vegetations in the lake's bed which become thicker. The dense enough vegetation of the lake Chad Basin has increased by about 28\% since 1990. Likewise, the thick vegetation made of Prosopis juliflora has become more and more invasive with an extension of more than $458 \%$ in relation to its surface in 1990.

\section{Discussion}

The analysis of the results from the surfaces of the different units of soil occupation crossed with the different observations on the field has indicated, in a general way, that the region of Diffa faces a climatic and anthropic pejoration, notably in the Lake Chad Basin area. These phenomena interact in a vicious circle of the type whether the hen or the egg preceded the other? The recurrent variations in rainfall (rarity and /or irregularity of rain) and other droughts modify the natural milieu [9; 10]. This situation brings out deep modifications to the vegetable cover. 
Certain herbaceous and woody plant species, formerly featuring the natural landscape of the environment, are more and more replaced by bad quality fodder species, less liked or disliked by animals. Thus, the herbaceous cover is dominated by a proliferation of Cenchrus biflorus, a plant species which has almost invaded all the pastoral and agropastoral pathways; Boleria sp; Sida cordifolia; Pergularia tomentosa (a robust and toxic plant) or also by species like Tragus (T berteronianus, T racemonus); etc. In fact, the rainfall statistics of the region of Diffa indicate that from 1990 to 2010 , one year over two is declared dry $[11 ; 12]$.

As for the aerial plants, we mostly notice the proliferation of Calotropis procera on the steppes. The strong pressure of this species on a field explains its level of degradation. This presence is also more and more observed in the Northern part of the region, in the pastoral zone. In other respects, the improvement in rainfall recorded during the recent years could explain the extension of the steppe as well as the densification of vegetations observed on the period taken into account in the zone of the Lake Chad.

The anthropic actions participate at large scale in the dynamics of soil occupation observed. As, Man, to satisfy his vital as well as economic needs, every day exploits, in one way or the other, the nature whose balance he always modifies. Some studies have reported nowadays that it is indisputable that Man exerts a considerable pressure on the natural resources $[8 ; 7 ; 6 ; 5]$. In fact, in the region of Diffa, the anthropic action is partially the cause of the changes observed on the natural resources in particular and on the balance of the environment in general [4; 13]. The extension of crop production, housing, the increase in livestock, etc., notably in the Southern part of the region explains the strong demographic pressure on the land reserve and on the natural resources. However, the statistics of soil occupation indicate a decrease in surface puts into farming in the area of the lake passing from 31\% in 1990 to $1.26 \%$ in 2018 . This could be partially due to the abandonment of farming areas in favor of vegetations in the lake's bed. In fact, because of the insecurity that prevails in the Lake Chad with the cruel attacks from the sect "Boko Haram" elements, entire villages were abandoned obliging the populations to leave the lake's bed and nature has taken its rights. This also could explain the displacement of farming towards the North, notably in the area of degraded shrub. The marginal lands are more and more grabbed at the expenses of the pastoral zones. It is for some actors a strategy of productive risk management and for others, a strategy of making the space a territory [11]. Similar situation was reported in other regions of Niger [14; $15 ; 9 ; 16 ; 17]$. This situation increases deforestation, the phenomenon of silting and the advancement of desert [9; 18; $19 ; 20]$. Thus, the competition for the access and control of land constitutes a major problematic for the rural actors.

\section{Conclusion}

This analysis shows that the landscape of the Lake Chad Basin is widely shaped by the conjugated influence of several factors, both natural and anthropic. These factors act on the productive capital of the area. The crop production fields give place at certain parts to vegetations which become dense in the lake's bed. Anyway, these elements significantly act on the entire systems of production of the populations in the region, which can exacerbate the competition between the actors. The dynamics of space's organization is observed, in terms of access, management and control of natural resources. In this multi-factor context (climatic, anthropic, socioeconomic, etc.) marked by uncertainty and risks, the rural actors develop diverse forms of strategies with the objective of securing their families as well as their productive basis.

\section{Compliance with ethical standards}

\section{Acknowledgments}

We would like to thank all those who facilitated our access to the data, in particular the regional directorate of agriculture of Diffa and that of the environment.

\section{Disclosure of conflict of interest}

All authors have no conflict of interest.

\section{References}

[1] Lona I. Risques climatiques et pratiques culturales du mil et du sorgho au Niger. [Geography Ph.D thesis], AGRHYMET Regional Center, Niamey (Niger). 2014.

[2] Conseil National de l'Environnement pour un Développement Durable. Seconde communication nationale du Niger sur le changement climatique. Niamey. Niger: Cabinet du Premier Ministre. 2009. 
[3] Institut National de la Statistique. Annuaire statistique 2014-2015. Ministère du Plan. Niamey (Niger). 2016.

[4] Republic of Niger. Contribution de la région de Diffa à la révision de la stratégie de réduction de la pauvreté au Niger. Comité régional de la révision de la Stratégie de réduction de la pauvreté. Région de Diffa. 2008.

[5] Lambin EF, Rounsevell MDA, Geist HJ. Are agricultural land-use models able to predict changes in land-use intensity? Agriculture, Ecosystems and Environment. 2000; 82(1-3): 321-331.

[6] Lambin EF, et al. The causes of land-use and land-cover change: moving beyond the myths. Global Environmental Change. 2001; 11(4): 261-269.

[7] Lambin EF, Geist H. Causes of land-use and land-cover change. The Encyclopedia of earth. (2007).

[8] Prakasam C. Land use and land cover change detection through remote sensing approach: a case study of Kodaikanal taluk, Tamil nadu. International Journal of Geomatics and Geosciences. 2010; 1(2): 150-158.

[9] Mai Moussa M. Impacts des changements climatiques sur les ressources naturelles et gestion des conflits inhérents par les agropasteurs de la région de Tahoua. [Ph.D. thèse], Faculté des lettres et sciences humaines, Département de géographie, Université Abdou Moumouni de Niamey, Niger. 2012.

[10] Ozer P, Erpicum M. Méthodologie pour une meilleure représentation spatio-temporelle des fluctuations pluviométriques observées au Niger depuis 1905. Sécheresse. 1995; 6(1): 103-108.

[11] Laouali A, Lebailly Ph. Analyse des systèmes de production des ménages pastoraux et agro-pastoraux dans la région de Diffa à l'est du Niger. Annale de l'Université Abdou Moumouni. Tome XXIII-A. 2018; 2: 129-141.

[12] Laouali A. Contribution à l'étude de la dynamique de l'élevage pastoral au Niger: cas de la région de Diffa. [Ph.D. Thesis]. Université de Liège - Gembloux Agro-Bio Tech, Gembloux, Belgique. 2014.

[13] Republic of Niger. Stratégie de développement rural (SDR). Ministère des Ressources animales. Niamey (Niger). 2003.

[14] Yamba B, Maccatory B. Les systèmes pastoraux au Niger, enjeux et viabilité. GRAP3A-Niger. Niamey (Niger). 2013.

[15] Yamba B, et al. Analyse de la vulnérabilité pastorale dans les départements de Abalak, Boboye et Dakoro. Rapport final. GRAP3A-Niger. Niamey (Niger). 2013.

[16] Institut National de la Statistique. Annuaire statistique des cinquante ans d'indépendance du Niger. Edition spéciale. : Ministère de l'Economie et des Finances. Niamey (Niger). 2010.

[17] Thébaud B. Gestion de l'espace et crise pastorale au Sahel: étude comparative du Niger oriental et du Yagha burkinabé. [Ph.D Thesis] : Ecole des Hautes Etudes en Sciences Sociales, Paris (France). 1999.

[18] Republic of Niger. Rapport annuel des statistiques. Ministère de l'élevage et des industries animales. Direction Régionale de Diffa. 2010.

[19] Republic of Niger. Monographie de la région de Diffa. Ministère de l'Aménagement du territoire et du Développement communautaire, Direction régionale de Diffa. 2008.

[20] Peyre De Fabregues B. Agropastoralisme et végétation. In: Les pâturages sahéliens d'Afrique de l'Ouest. Extraits des Atlas «Elevages et potentialités pastorales sahéliennes »: Tchad, Niger, Burkina Faso, Mali, Sénégal, Mauritanie. Wageningen, Pays-Bas/Montpellier, France : CTA/CIRAD/EMVT. 1994; 37-58. 